\title{
Nudging a Behavioural Change in Maritime Carriage of Goods - The Role of Information
}

\section{Eftestöl-Wilhelmsson, Ellen}

Edward Elgar

2019-10-01

Eftestöl-Wilhelmsson, E \& Sankari , S E 2019, Nudging a Behavioural Change in Maritime Carriage of Goods - The Role of Information . in J Chuah (ed.), Research Handbook on Maritime Law and Regulation. Research Handbooks in Private and Commercial Law series, Edward Elgar, Cheltenham , pp. 170-185 . https://doi.org/10.4337/9781786438799.00014

http://hdl.handle.net/10138/312543

https://doi.org/10.4337/9781786438799.00014

unspecified

acceptedVersion

Downloaded from Helda, University of Helsinki institutional repository.

This is an electronic reprint of the original article.

This reprint may differ from the original in pagination and typographic detail.

Please cite the original version. 


\section{Nudging a behavioural change in maritime carriage of goods - the role of information* Ellen Eftestøl-Wilhelmsson and Suvi Sankari}

\section{THE NEED FOR A BEHAVIOURAL SHIFT IN THE INDUSTRY}

The level of greenhouse gas (GHG) emissions from transport is unsustainable and is projected to increase. In addition to avenues successfully explored, such as international cooperation or technical standards and innovations, more could be done to persuade the industry to consider changing its own mind-set towards mitigating emissions from transport. Moreover, as discussed in more detail below, influencing the behaviour of the maritime shipping industry - the focus of this chapter - could be based on existing knowledge and information on emissions. On the one hand, some level of readjustment could be achieved by merely requiring that emissions information be visible in transport documents; on the other hand, an even bigger transformation could be achieved if transport-related emissions were integrated into consumer information on industrial products.

The global challenge set by transport generally is as follows. Of the total GHG emissions in the European Union (EU), transport is responsible for 25 per cent, being the second-largest-emitting sector after the energy sector, and industry is the third largest. ${ }^{1}$ International maritime shipping carries 90 per cent of EU imports and exports, ${ }^{2}$ accounting for around 2.5 per cent of the world's GHG emissions. Its emissions have increased by 22 per cent since 1990, and according to some estimates, international maritime shipping emissions could increase $50-250$ per cent by $2050 .^{3}$ In terms of a rise in passengers and tonne-kilometre demand since 1990, international maritime shipping is the second-fastest-growing transport sector in the EU after international aviation. ${ }^{4}$ Despite different transport policies and action plans on greening transport, the transport sector has not shown the same decline in emissions as the other

* This chapter builds on the authors' individual contributions in: Ellen EftestølWilhelmsson, Suvi Sankari and Anu Bask (eds), Sustainable and Efficient Transport: Incentives for Promoting a Green Transport Market (Edward Elgar Publishing, 2019).

1 European Commission, A European Strategy for Low-Emission Mobility (COM(2016) 501 final) ANNEX I: Historical developments in transport activity, energy use and emissions, pp. 89-90.

2 European Commission website <https://ec.europa.eu/transport/modes/maritime_en> accessed 19 March 2018.

3 European Commission website <https://ec.europa.eu/clima/policies/transport/shipping_en> accessed 19 March 2018.

4 European Environment Agency <https:/www.eea.europa.eu/data-and-maps/indicators/ transport-emissions-of-greenhouse-gases/transport-emissions-of-greenhouse-gases-10> accessed 19 March 2018. 
sectors. The development is not in line with the internationally agreed goal of keeping the global temperature increase below $2^{\circ} \mathrm{C}$ compared to pre-industrial levels, which requires worldwide emissions to be at least halved from 1990 levels by $2050.5^{5}$ There is hence a need for more sustainable development ${ }^{6}$ in the transport sector. The EU has set a 60 per cent emissions-reduction target, with regard to 1990 levels, for the entire transport sector by $2050 .^{7}$ EU's carbon dioxide $\left(\mathrm{CO}_{2}\right)$ emissions from maritime transport should be cut by at least 40 per cent from 2005 levels by 2050 - and if feasible by 50 per cent. ${ }^{8}$ Emissions from international shipping are, however, not included in the 40 per cent target set for the EU. ${ }^{9}$ As for international shipping, the EU is calling for a global approach in collaboration with the International Maritime Organization (IMO)..$^{10}$

The great global challenge, to which the transport emission-cutting targets relate, is global sustainability - that is, economic, social and environmental progress while staying within ecological planetary boundaries. ${ }^{11}$ From a regional point of view, the EU has framed different policies and action plans on a low-carbon economy deemed necessary for Europe to reach the agreed climate targets as well as to generally remain competitive. Two important policy programmes are: (1) the European Commission's ('Commission') plan for a European Circular Economy (CE), which aims at transforming the current economy into a sustainable $\mathrm{CE}$ where the value of products, materials and resources is maintained for as long as possible and the generation of waste is minimized; ${ }^{12}$ and (2) the Roadmap to a Single European Transport Area - towards a competitive and resource efficient transport system, ${ }^{13}$ where the Commission presents a vision, as well as a strategy, for a competitive and sustainable transport system. The Roadmap's goal is to facilitate growth in transport while simultaneously reaching the 60 per cent emissions-reduction target. ${ }^{14}$ As suggested by the Commission, the emissions target cannot be achieved by clean/green tech alone, and a behavioural shift

5 See n 3.

6 In the era of the Anthropocene, sustainable development can be defined as 'development that meets the needs of the present while safeguarding Earth's life-support system, on which the welfare of current and future generations depends', David Griggs et al., 'Policy: Sustainable Development Goals For People and Planet' (2013) 495 Nature 305 <www.nature.com/nature/ journal/v495/n7441/full/495305a.html> accessed 27 June 2016.

7 European Commission, Roadmap to a Single European Transport Area - Towards a Competitive and Resource Efficient Transport System (COM(2011) 144 final), p. 6.

8 Ibid 29.

9 Ibid.

10 More on the collaboration with the IMO in Section 3.

11 On planetary boundaries, Johan Rockström et al., 'Planetary Boundaries: Exploring the Safe Operating Space For Humanity' (2009) 14 Ecology and Society 2, 32. See also European Commission's European Political Strategy Centre (EPSC) 'Sustainability Now! A European Vision for Sustainability' (2016) EPSC Strategic Note 18, and art 3(3) Treaty on the European Union (TEU).

12 Closing the Loop - An EU Action Plan For the Circular Economy (COM(2015) 614 final).

$13 \operatorname{COM}(2011) 144$ final (n 7).

14 The 60 per cent target is set for 2050 and with reference to the emissions in 1990 (n 6).

Columns Design XML Ltd / Job: Chuah-Research_handbook_on_maritime_law_and_regulation / Division: 07Ch7-Eftestol_final /Pg. Position: 2 
in the industry is needed..$^{15}$ Multimodality, making use of more than one mode of transport under one contract of carriage, has been regarded as an important part of the solution since the very beginning of the 'green' transport policy in the early $1990 \mathrm{~s}^{16}$ and is still the core of the policy. EU Transport Commissioner Violeta Bulc has called for 2018 to be the 'Year of Multimodality' - a year during which the Commission will raise the importance of multimodality for the EU transport system. ${ }^{17}$ The idea is that the performance of multimodal logistic chains must be optimized, including making use of inherently more resource-efficient modes. ${ }^{18}$ However, neither policy instrument explicitly integrates transport as part of global supply chains in which products are made. Hence, we argue that, at present, the transport industry has insufficient incentives to change its behaviour.

This chapter discusses how the maritime freight transport sector can be transformed into a green industry where environmental concerns are integrated into everyday decisions. It builds on the idea that information is the key to change. This chapter hence starts out by introducing the concept of nudge and the power of information on emissions as an incentive or a nudge, which can push the actors in the supply chain to take environmental issues into concern when making their day-to-day decisions (Section 2). To nudge is to 'push mildly or poke gently ...' a theory of how behaviour can be altered by small interventions. ${ }^{19}$ In a way, this chapter aims to suggest a better choice architecture for supply chains as well as end consumers. The chapter continues by outlining the existing policy instruments and international (environmental) regulation targeted at international maritime shipping emissions (Section 3). For reasons of information asymmetry, freight transport of goods tends to remain the business of shippers or freight forwarders and maritime cargo carriers. Hence, we discuss how emissions information should be applied - first, in a way that it would work as a more direct nudge in the relationship between shippers or freight forwarders and the maritime transport industry, nudging the former which, in turn, would press the latter to become more green and, second, in a more indirect way through nudging consumers whose behaviour could, in turn, induce market-led change in the maritime transport industry (Section 4) - before ending with a concluding discussion (Section 5).

\section{THE POWER OF INFORMATION - NUDGING}

Our first proposition is that parties in the supply chain are more likely to make smart, green and integrated decisions when sufficiently informed about the environmental impacts of different transport alternatives. We start on the note that the technological

\footnotetext{
$15 \operatorname{COM}(2011) 144$ final (n 7), p. 43.

16 On the EU policy on multimodal carriage, see Ellen Eftestøl-Wilhelmsson, European Sustainable Transport of Goods - The Role of Contract Law (Routledge 2015).

17 Commission website <https://ec.europa.eu/transport/themes/logistics-and-multimodaltransport/2018-year-multimodality_en> accessed 26 March 2018.

$18 \operatorname{COM}(2011) 144$ final (n 7), p. 19.

19 Richard H Thaler and Cass R Sunstein, Nudge. Improving Decisions about Health, Wealth, and Happiness (Yale University Press 2008) 4.
} 
solutions for measuring and sharing information on emissions from transport, the so-called carbon footprints or GHG emissions, ${ }^{20}$ are already available. Hence, this chapter will not engage in the technical questions related to developing a harmonized system for calculating carbon footprints of transport. The Commission has launched several research projects on measuring carbon footprints from transport such as the now-ended COFRET project. ${ }^{21}$ The COFRET project has identified gaps and ambiguities within the existing methods for the calculation and declaration of energy consumption and GHG emissions from transport services (freight and passengers). ${ }^{22}$ In its end report, the COFRET project states: 'The next step will need to be driven by the industry actors (shippers, transport operators and logistic suppliers). It is these groups who can make the decisions that will improve the efficiency of operating practices and switch supply chain configurators to lower emission alternatives.'23 In other words, in addition to technical solutions, there is a need for a mind-set shift in the industry. The question is whether environmental information, when presented in the right way, could nudge the parties in the right direction.

The EU transport policies and action plans presented above all recognize that the climate goals will not be reached unless, in addition to green technical and digital solutions, a behavioural shift in the industry takes place. ${ }^{24}$ Accordingly, behavioural insight is increasingly used as a tool to achieve more efficient policy instruments. It was the behavioural economist Richard Thaler and law scholar Cass Sunstein who invented the term nudge in their 2008 book: Nudge. Improving Decisions about Health, Wealth, and Happiness. 25 Thaler and Sunstein define nudges as any aspect of the decision environment '.. that alters people's behavior in a predictable way without forbidding any options or significantly changing their economic incentives' ${ }^{26}$ The idea is, in other words, that through interventions of different kinds, people's choices can be affected in a way that makes people choose what is considered the more desirable alternative (for example, the choice to take the stairs instead of the elevator). The interesting part is that a nudge alters behaviour while maintaining the freedom of choice of the person who makes the decision. In this perspective, policymakers are seen as choice architects who facilitate the way people make choices. The term choice architecture reflects the fact that there are many ways to present a choice to the

20 According to the European Environmental Agency (EEA), for example, in international maritime shipping it is neither necessary to rely on theoretical estimations regarding emissions (not considering, for example, actual speed) nor to collect the data through private environmental or emissions standards because the Automatic Identification System (AIS) required by IMO already records more than enough data for reliable emissions modelling. See EEA, 'The Impact of International Shipping on European Air Quality and Climate Forcing' (technical report No 4/2013, 16) <https://www.eea.europa.eu/publications/the-impact-of-international-shipping/file> accessed 19 March 2018.

21 COFRET, Carbon Footprint of Freight Transport <https://trimis.ec.europa.eu/project/ carbon-footprint-freight-transport> accessed 19 March 2018.

22 COFRET, Final Result, 2 <www.cofret-project.eu/downloads/pdf/COFRET\%20results\% 20report_final.pdf> accessed 19 March 2018.

23 Ibid 11.

$24 \operatorname{COM}(2011) 144$ final (n 7), p. 43.

25 Thaler and Sunstein (n 19).

26 Ibid 8. 
decision maker and that what is chosen depends often upon how the choice is presented.27 In the first chapter of the book, Nudge and the Law: A European Perspective, Sibony and Alemanno discuss the legal dimension of nudging. ${ }^{28}$ The authors claim that nudging meets the law in two circumstances. The first is when private entities nudge their consumers, employees or potential donors into a desired behaviour, ${ }^{29}$ and the second is when public entities seek to nudge citizens into a certain behaviour. ${ }^{30}$ In both cases, the entity to be nudged is a consumer or a private person (citizen).

Indeed, nudges are studied mostly in relation to so-called business-to-consumer (B2C) relationships. ${ }^{31}$ However, firms are also subject to cognitive biases and can hence benefit from nudges. ${ }^{32}$ Firms are not theoretical entities or 'black boxes' ${ }^{33}$ Human beings, individual managers, boards or employees make decisions in firms, and hence, behavioural insight can be applied to these decisions as well. Decisions made by firms are, in other words, not strictly rational. ${ }^{34}$ On the contrary, decision making in firms can be nudged with interventions, such as providing information in the right context and at the right time. ${ }^{35}$ Information is an essential part of the nudging 'package'. Although the discussion and debate around nudging and behavioural insight has evolved to fine-tuning and reformulating the concept of nudge, ${ }^{36}$ for Sunstein, giving information remains one form of nudging, of influencing choice. ${ }^{37}$ In fact, information is described as the most predominant type of nudging, understood to be a 'promising tool to increase pro-environmental choices' ${ }^{38}$ However, information as such

27 Eric J Johnson et al., 'Beyond Nudges: Tools of a Choice Architecture' (2012) 23(2) Mark Lett 1.

28 Anne-Lise Sibony and Alberto Alemanno, 'The Emergence of Behavioural PolicyMaking: A European Perspective' in Anne-Lise Sibony and Alberto Alemanno (eds), Nudge and the Law: A European Perspective (Hart Publishing 2015).

29 Ibid 10.

30 Ibid 11.

31 See, for example, Hans-W Micklitz, Lucia A Reisch and Kornelia Hagen, 'An Introduction to the Special Issue on "Behavioural Economics, Consumer Policy, and Consumer Law" (2011) 34(3) J Consum Policy 271.

32 Mark Armstrong and Steffen Huck, 'Behavioral Economics as Applied to Firms: A Primer' (2010) No. 2937 CESifo Working Paper Series.

33 Andreas Heinemann, 'Behavioral Antitrust A "More Realistic Approach" to Competition Law' in Klaus Mathis (ed), European Perspectives on Behavioural Law and Economics (Economic analysis of law in European legal scholarship vol 2. Springer International Publishing 2015) 214.

34 Ibid 212

35 Geneviève Helleringer and Anne-Lise Sibony, 'European Consumer Protection through the Behavioral Lens' (2016-2017) 23 Colum. J. Eur. L. 607, 627-28.

36 See, for example, Pelle Guldborg Hansen, 'The Definition of Nudge and Libertarian Paternalism: Does the Hand Fit the Glove' (2016) 7 Eur. J. Risk Reg. 155.

37 Cass R Sunstein, Why Nudge?: The Politics of Libertarian Paternalism (Yale University Press 2014) 55

38 Anne SE Nielsen, Henrik Sand and Pernille Sørensen, 'Nudging and Pro-Environmental Behaviour' (TemaNord, Nordic Council of Ministers 2017) 8. 
does not always lead to the wanted behavioural effect. ${ }^{39}$ The information must be tailored and often coupled with other nudges (for example social norms) to give the wanted effect. ${ }^{40}$

The Commission has already recognized the power of information as an important tool to promote sustainable transport. A report from 2016 discloses that the EU has exploited behavioural insights in its policymaking since 2008.41 Information on emissions related to different optional choices of modes of transport play a key role in the current European transport strategy. As stated by the Commission in 2011: 'Information on all modes of transport ... on possibilities for their combined use and on their environmental impact, will need to be widely available'. ${ }^{42}$ The idea is that such information will trigger more sustainable behaviour and help the parties make the right decisions..$^{43}$ Information is consequently a common denominator in the list of initiatives for promoting more sustainable behaviour, annexed to the 2011 roadmap to a Single European Transport area. ${ }^{44}$ Lack of information is in turn related to the lack of push for intermodal transport, which should be environmentally friendlier than, for example, road haulage alone. ${ }^{45}$

\section{INFORMATION ON GREENHOUSE GAS EMISSIONS IN SHIPPING}

\subsection{The Current System - Measuring, Reporting and Verifying}

Information is the key to promoting more sustainable behaviour. This holds true in international transport, which otherwise seems atypically 'excluded' in fields relating to climate goals and obligations. Neither international aviation nor international maritime transport were, for example, included in the 2015 Paris Climate Agreement. Within the $\mathrm{EU}$, transport seems to be considered a realm of its own and has to a large degree been excluded from the EU emissions trading system (ETS). Since 2012, however, aviation emissions have been included in the EU ETS. ${ }^{46}$ Within the EU ETS, a cap is set for the total amount of emissions per sector, but the actors participating in the system can trade

39 Folke Ölander and John Thøgersen, 'Informing Versus Nudging in Environmental Policy' (2014) 37(3) J. Consum. Policy 341, 354.

40 Ibid.

41 Joana Sousa Lourenço et al., Behavioural Insights Applied to Policy: European Report

2016 (EUR vol 27726, Publications Office 2016) 37.

$42 \operatorname{COM}(2011) 144$ final (n 7) 48.

43 Ibid Annex 2.2.

44 Ibid Annex 1, 2.2, pp. 27 and 30.

45 Anu Bask and Mervi Rajahonka, 'The Role of Environmental Sustainability in the Freight Transport Mode Choice: A Systematic Literature Review With Focus on the EU' (2017) 47(7) International Journal of Physical Distribution \& Logistics Management 560.

46 See Emilie Yliheljo 'Possibilities and Regulatory Barriers for Regulating GHG Emissions from Transport Using the European Emissions Trading Scheme' in Ellen Eftestøl-Wilhelmsson, Suvi Sankari and Anu Bask (eds) Sustainable and Efficient Transport: Incentives for Promoting a Green Transport Market (Edward Elgar Publishing, forthcoming 2019). 
emissions among themselves. All airlines operating in Europe, both European and non-European, are required to monitor, report and verify (MRV) their emissions and to surrender allowances against those emissions. The airlines receive tradeable allowances that cover a certain level of emissions from their flights per year. According to the Commission, the system has so far contributed to reducing the carbon footprint of the aviation sector by more than 17 million tons per year, with compliance covering over 99.5 per cent of emissions. ${ }^{47}$

Other transport sectors are so far excluded from the EU ETS. Nevertheless, these sectors will need to make their contributions to achieving the demanding climate goals. The EU Member States have agreed on the level of emission cuts for each Member State for the period 2013-2020 in the Effort Sharing Decision. ${ }^{48}$ According to the decision, all sectors of the economy should contribute to achieving the emissions reductions, including international maritime shipping, which, as mentioned, has so far been excluded from the EU emissions-reduction programmes. Instead, the EU has decided on a global approach for international shipping because this is considered the most effective way to approach the emissions problem. ${ }^{49}$ The IMO has a leading role in the process of reducing emissions from international maritime transport. The mandate from the EU is, however, conditional. According to the preamble of the Effort Sharing Decision, in the event that no international agreement was approved by 2011, the Commission would make a proposal to include international maritime emissions in the community reduction commitment, with the aim of the proposed act entering into force by 2013.50

In 2011, the IMO agreed on a set of (global) technical performance standards for measuring emissions from both new and old ships. The standards were implemented in 2011 by amendments to the International Convention for the Prevention of Pollution from Ships (MARPOL), Annex VI.51 The aim of the amendments was to improve energy efficiency for ships through these standards, which are estimated to result in emissions reductions of any substances that originate from fuel oil and its combustion process $^{52}$ and thereby cost-effectively promote emissions reductions from maritime transport. The system is flexible so that the industry can benefit from future technical innovations. To receive an 'International Air Pollution Preventive Certificate' or an

47 Commission website <https://ec.europa.eu/clima/policies/transport/aviation_en> accessed 5 March 2018.

48 See art 3 and Annex II of Decision No 406/2009/EC of the European Parliament and of the Council of 23 April 2009 on the effort of Member States to reduce their greenhouse gas emissions to meet the Community's greenhouse gas emissions-reduction commitments up to 2020.

49 Commission website <https://ec.europa.eu/clima/policies/transport/shipping_en>, accessed 19 March 2018.

50 Decision No 406/2009/EC (n 48), 2nd Recital of the Preamble.

51 Resolution MEPC.203(62) adopted on 15 July 2011 Amendments to the Annex of the Protocol of 1997 to amend the International Convention for the Prevention of Pollution from ships, 1973, as modified by the Protocol of 1978 relating thereto (Inclusion of regulations on energy efficiency for ships in MARPOL Annex VI) see <www.imo.org/en/OurWork/ Environment/PollutionPrevention/AirPollution/Documents/Technical\%20and\%200perational\%20 Measures/Resolution\%20MEPC.203(62).pdf> accessed 20 March 2018.

52 Ibid. 
'International Energy Efficiency Certificate', the vessel needs to comply with the applicable emissions standards, which will become stricter over time. The first phase aims at a reduction of 10 per cent of $\mathrm{CO}_{2}$ emissions, whereas the goal for the post-2025 phase is a 30 per cent reduction in emissions..$^{53}$

The EU has furthermore decided that all large vessels visiting EU ports must comply with the measurement standards adopted by the IMO. Regulation 2015/757 (as amended by Delegated Regulation 2016/2071) on the MRV of $\mathrm{CO}_{2}$ emissions from maritime transport ${ }^{54}$ is aligned with the IMO standards outlined above. The MRV system of $\mathrm{CO}_{2}$ emissions from shipping has started taking place on a per-voyage basis from 1 January 2018.55 The information is reported to the Commission and to the authorities of the flag state on an annual basis with the first deadline being 30 April 2019.56

There are, however, diverging opinions on how effective the system will be. In the best-case scenario, the specific energy consumption and $\mathrm{CO}_{2}$ emissions of ships could be reduced by up to 75 per cent by applying operational measures and implementing existing technologies.57 However, neither the Council nor the European Parliament seem to be satisfied with the current solution. The problem is that no specific emissions-reduction goals have been set in regards to international shipping. Both the Council and the Parliament have recently addressed this issue. The Council has urged the IMO to set up a GHG emissions-reduction strategy in the IMO meeting, which took place in April 2018.58 Moreover, the Parliament has proposed that unless IMO agrees to take action to tackle maritime $\mathrm{CO}_{2}$ emissions, the $\mathrm{EU}$ should, from 2023, extend the EU ETS to account for emissions of international shipping during voyages to and from EU ports. ${ }^{59}$ In the April 2018 meeting, however, IMO adopted an initial strategy on the

53 The Energy Efficiency Design Index (EEDI) applies to new ships built from 2013 onwards, and since 2011, all ships are compulsorily required to have a 'Ship Energy Efficiency Management Plan' (SEEMP). The EEDI provides a specific figure for an individual ship design, expressed in grams of $\mathrm{CO}_{2}$ per ship's capacity-mile (the smaller the EEDI, the more energy efficient ship design) and is calculated by a formula based on the technical design parameters for a given ship. See IMO, 'Energy Efficiency Measures'<www.imo.org/en/ourwork/environment/ pollutionprevention/airpollution/pages/technical-and-operational-measures.aspx $>$ accessed 20 March 2013.

54 European Parliament and Council Regulation (EU) 2015/757 on the monitoring, reporting and verification of carbon dioxide emissions from maritime transport and amending Directive 2009/16/EC.

55 Ibid 39th Recital of the Preamble.

56 Ibid art 11(1).

57 Ibid 9th Recital of the Preamble.

58 Council Conclusions on Climate Diplomacy - Council Conclusions (26 February 2018), at point 20 , p. 8 , <http://data.consilium.europa.eu/doc/document/ST-6125-2018-INIT/en/pdf> accessed 19 March 2018.

59 European Parliament <www.europarl.europa.eu/legislative-train/theme-resilient-energy-unionwith-a-climate-change-policy/file-greenhouse-gas-reduction-targets-for-international-shipping $>$ accessed 19 March 2018. 
reduction of GHG emissions from ships. ${ }^{60}$ The vision is now to reduce GHG emissions from international shipping and to phase them out 'as soon as possible in this century' ${ }^{61}$ IMO has furthermore set a goal of reducing $\mathrm{CO}_{2}$ emissions per transport work by at least 40 per cent by 2030 and 70 per cent by 2050 , which is in line with the United Nations 2040 Agenda for Sustainable Development. The strategy will be revised in $2023 .{ }^{62}$

\subsection{Is the Choice Architecture Correct in the Current System?}

While evaluating the current system from the perspective of achieving a behavioural shift in maritime freight carriage, one might ask if measuring and reporting the information is enough to reach the internationally agreed goal of keeping the global temperature increase to below $2^{\circ} \mathrm{C}$ compared to pre-industrial levels..$^{63}$ The messages from the EU Council and Parliament indicate some scepticism in this regard. If we apply the nudging theory to the situation, measures should be established that would make sustainable carriage the default choice of the maritime transport service users. With regard to shipped cargo, these are the freight forwarders and shippers.

The impact of the MRV system outlined above is that ship owners and operators shall monitor the $\mathrm{CO}_{2}$ emissions of their vessels per voyage conducted into, between and out of the EU (and the European Free Trade Association, EFTA) ports according to different parameters. The Commission should make some of the information publicly available. From the perspective of nudging towards green carriage of cargo, information related to 'the annual average fuel consumption and $\mathrm{CO}_{2}$ emissions per distance travelled and cargo carried on voyages' is essential. ${ }^{64}$ The idea is that if the freight forwarders and shippers could access information on the potential $\mathrm{CO}_{2}$ emissions from their cargo being carried, they would have the option to choose the less-polluting alternative of carriage. Changing the choice architecture by making it mandatory to always include this information in the transport contract document would be one way of nudging a behavioural change in the transport industry by small means. All that is needed is a small change to the transport document related to the carriage of the cargo, which in shipping is the Bill of Lading. Practically, a new text box could be added to the front page of the document with the information on the amount of $\mathrm{CO}_{2}$ emissions related to the carried cargo. The difference from the current system would only be that the information would be provided in relation to specific cargo on a specific voyage.

A stronger nudge than mandatory disclosure of emissions per cargo carried would mean changing the choice architecture into one where the Bill of Lading would not just disclose emission amounts in numbers. For example, similar to the EU Energy

60 International Maritime Organization, 'Note by IMO to the UNFCCC Talanoa Dialogue. Adoption of the Initial IMO Strategy on Reduction of GHG Emissions from Ships and Existing IMO Activity Related to Reducing GHG Emissions in the Shipping Sector' <https://unfccc.int/ sites/default/files/resource/250_IMO\%20submission_Talanoa\%20Dialogue_April\%202018.pdf> accessed 26 June 2018.

61 Ibid Annex 1 at 2.

62 Ibid Annex 1 at 7.

63 See $n 3$.

64 Art 21(f) of Regulation (EU) 2015/757 (n 54). 
Labelling Directive that concerns many household appliances, the level of transport emissions could be expressed by how they rank on a scale from A (greenest) to $\mathrm{G}$ (least green) (Figure 7.1). ${ }^{65}$ Such classification and presentation would be a stronger nudge for shippers and freight forwarders to visibly make green choices on the maritime freight carriage market. Moreover, the same approach could be used with different forms of freight transport, and it perhaps could make its way into information given to the end consumer of carried products as well - for example, stating that transport emissions throughout the global supply chain producing this product fall within class B or lower.

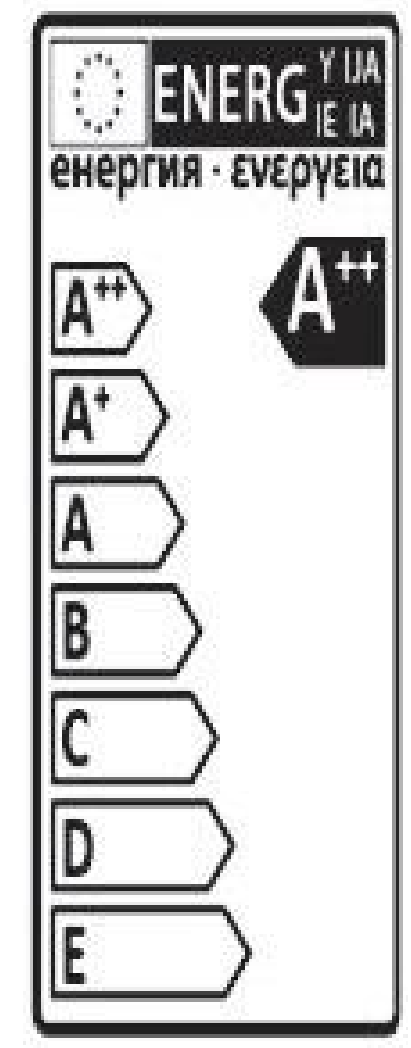

Source: Commission Delegated Regulation (EU) No 874/2012 of 12 July 2012 supplementing Directive 2010/30/EU of the European Parliament and of the Council with regard to energy labelling of electrical lamps and luminaires (Text with EEA relevance) <http://data.europa.eu/eli/reg_del/2012/874/2017-03-07> accessed 11 March 2019.

Figure 7.1 EU Energy Label Scale

65 For an illustration, see, for example, Commission website <https://ec.europa.eu/energy/en/ topics/energy-efficiency/energy-efficiency-directive> accessed 26 June 2018. 


\section{THE IMPACT OF CONSUMER DEMAND ON GREEN FREIGHT}

We have established that emissions information on transport, especially in maritime cargo shipping, is already available and could be used to nudge the transport industry into more sustainable choices. In addition to changing the choice architecture in contracting between shippers or freight forwarders and cargo carriers, emissions information could be included in the product information given to the consumers. After all, transporting products through global supply chains and beyond forms part of the ecological footprint of products. At the moment, the products circulating on the market and information on transport-related emissions caused by their production and carriage in the global supply chains are wholly disjointed from each other, from the perspective of the product's end user. The information on transport-related emissions is only selectively, or not at all, made available to the end consumer choosing between products to purchase. As end buyers are isolated from this environmental aspect of the product, a market-led incentive for changing the behaviour of freight forwarders and shippers (in turn changing the mind-set of carriers and operators) is missed; as for lack of consumer information, such an incentive does not arise out of consumer market demand.

Marketing literature suggests that some consumer demand for green products exists. ${ }^{66}$ Consumers are no longer solely interested in the physical product, such as the materials used for production and packing, but also wish to know, for instance, where the raw materials were produced, purchased and transported. ${ }^{67}$ Moreover, many consumers take an interest in what happens to the product after its lifetime - as waste. In other words, consumers are increasingly interested in the social and environmental impact of the entire life cycle of products, including both forward and reverse supply chains. ${ }^{68}$ As for companies, they have been under increasing pressure to consider the environmental effects of their products and services during the past 20 years, ${ }^{69}$ both because of market-led demand and regulatory requirements relating to Corporate Social Responsibility (CSR). ${ }^{70}$ In order to keep the consumers fully informed of the total

66 Literature suggests, first, that the size of the green consumer segment is 35 per cent (Arminda M Finisterra do Paço, Mário Lino Barata Raposo and Walter Leal Filho 'Identifying the Green Consumer: A Segmentation Study' (2009) 17(1) Journal of Targeting, Measurement and Analysis for Marketing 17,23) and, second, that when choosing between two otherwise identical products, almost all consumers pick the 'green' one. Originally, WJ Kardash, 'Corporate Responsibility and the Quality of Life: Developing the Ecologically Concerned Consumer', in Karl E Henion and Thomas C Kinner (eds) Ecological Marketing (American Marketing Association 1974).

67 Anu Bask, Merja Halme, Markku Kallio and Markku Kuula, 'Consumer Preferences For Sustainability and Their Impact on Supply Chain Management: The Case of Mobile Phones' (2013) 43(5/6) IJPD\&LM 380.

68 Ibid.

69 Paul R Kleindorfer, Kalyan Singhal and Luk N van Wassenhove, 'Sustainable Operations Management' (2005) 14(4) Production and Operations Management 482.

70 Mette Andersen and Tage Skjoett-Larsen, 'Corporate Social Responsibility in Global Supply Chains' (2009) 14(2) Supply Chain Management: An International Journal 75-86; C Clifford Defee, Terry Esper and Diane Mollenkopf, 'Leveraging Closed-Loop Orientation and 
environmental impact of a product, the environmental impact of transport should be integrated in product information. Product information about transport emissions can be considered a nudge towards purchasing greener products. It would be the slightest change imaginable in the choice architecture concerning consumer transactional decisions while preserving - in fact, enhancing - consumers' freedom of choice. This move is not envisioned in the Commission's plan for a European CE, although one of its essential objectives is to help consumers choose sustainable products and services. ${ }^{71}$ Hence, at the moment, transport at large remains the target of more or less stringent technical requirements and monitoring measures, wholly isolated from the products carried and thereby largely insulated from market-led incentives for cutting emissions.

Currently, the mind-set of neither industry, regulators nor consumers builds on the idea that transport within global supply chains should be integrated into emissions data and product information. Transport is considered a service distinct from the product being transported, although these services clearly form an integral part of global supply chains. ${ }^{72}$ From the point of view of supporting the choice of more sustainable products, the mind-set would have to change into one where transport emissions of global supply chains would be integrated into product information, either as an independent category of information or as part of the ecological footprint of the product. While consumers hold an abundance of (mixed) preferences, when polled, 40 per cent of the European population signals willingness to pay more for goods that are "produced under certain social and environmental standards' ${ }^{73}$ A relatively large portion of consumers would be interested in the environmental aspects of products and, in terms of affecting the market, a high enough portion of them seems to be willing to pay a premium for green products. One central missing bridge between 'green will' and market-led change is access to (encompassing and reliable enough) information on which to base choices. ${ }^{74}$ This is where the policymakers or regulators as choice architects should step in but have not.

Arguably, CSR measures directed to businesses, such as the EU Directive on disclosing non-financial information ${ }^{75}$ adopted in 2014 , are not enough to dismantle barriers to greener consumption from the consumer perspective. The Directive suggests large companies should, from 2017 onwards, consider reporting the "environmental

Leadership For Environmental Sustainability' (2009) 14(2) Supply Chain Management: An International Journal 87-98.

71 Commission website <https://ec.europa.eu/commission/sites/beta-political/files/circulareconomy-factsheet-consumption_en.pdf> accessed 19 March 2018; Commission 'Closing the Loop' (n 12).

72 At an abstract-enough level, the Commission includes transport as part of its definition of what a supply chain consists of. See Commission Staff Working Document: Sustainable Garment Value Chains through EU Development Action (SWD(2017) 147 final) 5.

73 Special Eurobarometer 357 'International Trade', 2010, 43: 'A significant proportion of Europeans are willing to pay more for products which help the environment, respect social standards, help developing countries or which are made in their countries.'

74 Mark R Gleim et al., 'Against the Green: A Multi-Method Examination of the Barriers to Green Consumption' (2013) 89(1) Journal of Retailing 44, 57-58.

75 European Parliament and Council Directive 2014/95/EU amending Directive 2013/34/EU as regards disclosure of non-financial and diversity information by certain large undertakings and groups (OJ L 330, 15.11.2014, pp. 1-9). 
impacts from transportation' as well as GHG emissions of their supply chain as key performance indicators. ${ }^{76}$ The Directive requires that companies report, among other things, a review of their policies (or non-policies), principal risks and outcomes on environmental issues. It leaves relatively open both the methods for gathering information - the use of certain guidelines or methods is recommended but not obligatory ${ }^{77}$ - and where and how it is reported. Hence, reporting will not take place on product labels accessible to consumers, the reports of different companies will not follow the same format and the information reported in them (including emissions information) will not be readily comparable across reports even with companies in the same industry sector because of differences in standards and methodologies applied to produce the emissions information. The Directive is closer to a company than a product standard as it in no way requires disclosing non-financial information to consumers on, for example, labels attached to individual products sold. In essence, the Directive does not change the status quo that companies can choose between different voluntary standards or different degrees of the same voluntary standard for reporting on sustainabilityrelated issues. ${ }^{78}$

There are significant differences between standards, as well as between different degrees of the same environmental standard, regarding whether or not they include parts of transport-related emissions along the (global) product supply chain. It is easy to find voluntary private standards that do not consider the international maritime transport leg of all transport, which the global supply chain requires. Hence, private standards are mostly for the benefit of ethical investors or particularly enlightened consumers - if not for greenwashing. ${ }^{79}$ The potential value of information that builds on voluntary standards may offer some comparability between those manufacturers who use the same standards but not across those who use different standards. Hence,

76 Commission Communication, 'Guidelines on non-financial reporting (methodology for reporting non-financial information)' (2017/C 215/01), p. 15. Though the 21 st Recital of the (Amendment) Directive's Preamble states that its objective is to increase the relevance, consistency and comparability of information disclosed by certain large undertakings and groups across the Union', one can assume that the reporting duty itself as well as what is reported should in turn affect both the company and the market behaviour.

77 For instance, using national, European or international guidelines (UN Global Compact) is encouraged, and the Commission guidelines refer to methods specified in Commission Recommendation 2013/179/EU annexes, which include Product Environmental Footprint and Organisation Environmental Footprint.

78 One option for companies is the private 'GHG Protocol Corporate Standard' (GHGPCS), which allows a choice between what is reported ('scopes'): direct GHG emissions covered by the Kyoto Protocol that 'occur from sources that are owned or controlled by the company' including, for example, vehicles ('scope 1'); accounting 'for GHG emissions from the generation of purchased electricity consumed by the company' ('scope 2'); indirect GHG emissions - the sources of which are 'not owned or controlled by the company' ('scope 3'). See <www.ghgprotocol.org/corporate-standard> accessed 19 March 2018.

79 For a critical view on the relationship between legal rules on unfair commercial practices and CSR advertising, see Jules Stuyck, 'Corporate Social Responsibility-Standards and the Belgian and French Perspective', in Reto M Hilty and Frauke Henning-Bodewig (eds), Corporate Social Responsibility. MPI Studies on Intellectual Property and Competition Law, vol 21 (Springer 2014) 225-32. 
the use of different private (green service or company) standards works in this context just like it does in so many other contexts: 80 the incommensurability of standards - or more precisely, that of the information they provide - would make informed choices overly difficult for the buyers of transport services and end products.

\section{CONCLUDING DISCUSSION}

The regulatory requirements posed on the maritime transport industry, (transport) companies' reporting duties and the fact that plenty of manufacturers, retailers and shippers subscribe to voluntary standards ${ }^{81}$ mean that, on average, a lot of transport emissions information readily exists within (global) supply chains. ${ }^{82}$ However, adequate mechanisms are not yet in place to ensure this information reaches the buyers of transport services (shippers and freight forwarders) or the consumers of products, and hence, the transformative potential of nudging the choices of buyers and consumers by providing that information is lost.

Establishing the choice architecture sketched above - in other words, requiring service providers to disclose information on product labelling - is not far-fetched from a legal point of view. For example, whether traders, regardless of their private standard commitments, are obliged to disclose the information they have on transport-related emissions of a given product (or service) - or the consumers' right to that information ${ }^{83}$ - could fall under the existing Unfair Commercial Practices Directive (UCPD) ${ }^{84}$ This information could be considered material and could affect the (average) consumer's transactional decisions on products or services; the omission could breach consumers' rights under the UCPD. However, the UPCD is not currently interpreted this way, and

80 The typical market failure problems that standards give rise to are often considered to require intervention by the legislator. See Douglas A Kysar, 'Preferences for Processes: The Process/Product Distinction and the Regulation of Consumer Choice' (2004) 118 Harvard Law Review, 526, 626. However, assuming constant technical development, the problem that arises after intervention is that legislating (mandatory standard setting) is typically a slow process, and hence, the standards it sets will constantly lag behind technical development. See Carl Dalhammar, 'Promoting Energy and Resource Efficiency through the Ecodesign Directive' (2014) 59 Scandinavian Studies in Law, 147, 176.

81 For example, ISO/IWA 16:2015 International harmonized method(s) for a coherent quantification of $\mathrm{CO}_{2}$ emissions of freight transport <https://www.iso.org/obp/ui/\#iso:std:iso:i wa:16:ed-1:v1:en> accessed 19 March 2018.

82 See, for example, nn 20 and 53.

83 In more detail, see Suvi Sankari 'Product Information on Freight Emissions for Consumers - Changing the Market towards Sustainability?' in Ellen Eftest $\varnothing 1$-Wilhelmsson, Suvi Sankari and Anu Bask (eds), Sustainable and Efficient Transport: Incentives for Promoting a Green Transport Market (Edward Elgar Publishing, forthcoming 2019).

84 Cf. art 7 of Directive 2005/29/EC of the European Parliament and of the Council of 11 May 2005 concerning unfair business-to-consumer commercial practices in the internal market and amending Council Directive 84/450/EEC, Directives 97/7/EC, 98/27/EC and 2002/65/EC of the European Parliament and of the Council and Regulation (EC) No 2006/2004 of the European Parliament and of the Council ('Unfair Commercial Practices Directive') (OJ L 149, 11.6.2005, pp. 22-39). 
no present regulation or policies we are aware of - such as the CE package - envision changing that interpretation or integrating transport-related emissions into service and product information in some other way. Moreover, the practical enforcement of the rights conferred by the Directive would remain another matter. Such a possible alternative interpretation of the existing law nevertheless implies that it would not be wholly unimaginable to include emissions information as part of traders' mandatory informational duties ${ }^{85}$ For instance, though based on national climate strategy instead of consumer protection, national French legislation ${ }^{86}$ has made the disclosure of $\mathrm{CO}_{2}$ emissions mandatory for all transport services since October 2013 and relies on the CEN 16258 standard. 87

Taking the aforementioned discussion and examples into account, it is no surprise to $\mathrm{EU}$ and international regulators that information on transport-related emissions on service and product supply chains already exists. What may be holding the choice architects back is, on the one hand, the issue of incomparability of emissions information and the question of its reliability and, on the other hand, common or multilateral solutions instead of unilateral moves, which are preferred for tackling climate change (while preserving competitiveness). Emissions information may not be totally comparable because of differences in the methodologies of what is included and how emissions are measured, but we consider the former point as a rather moot excuse for doing nothing. Especially in the field of maritime freight shipping, as it concerns EU-related legs of that transport, reliable and readily accessible information on GHG emissions exists from 2018 onwards. The latter aspect of avoiding unilateralism may, however, explain why the relative inertia of the IMO has not led the EU to adopt more drastic measures than it has thus far done. We might speculate that this is why the EU has not been prone to further unilateral (extraterritorial) solutions to transnational issues by, for example, introducing mandatory measures in its market, requiring disclosure of transport-related emissions on all products and services marketed there. ${ }^{88}$ However, as internal to EU carriage, an information requirement could be integrated into the proposed EU electronic transport document, which is in the making. ${ }^{89}$

85 Under this Directive, the duty is textually framed as a duty not to omit such information; however, this can be interpreted as a duty to disclose it. See also Geraint Howells, HansWolfgang Micklitz and Thomas Wilhelmsson, European Fair Trading Law (Ashgate 2006), especially $141 \mathrm{ff}$.

86 Transport Code, Article L. 1431-3; Decree no. 2011-1336 of 24 October 2011.

87 CEN 16258, 'Methodology for calculation and declaration of energy consumption and GHG emissions of transport services (freight and passengers)'.

88 An over-researched but still unclear related issue is the acceptability of setting process and production-method-based measures (PPMs), such as mandatory disclosure of transport-related emissions integrated in global supply chains might be under EU law alone and with World Trade Organization (WTO) law. For one arguing the incompatibility issue is exaggerated, Laurens Ankersmit, Green Trade and Fair Trade in and with the EU: Process-Bbased Measures within the EU Legal Order (CUP 2017). On WTO, see Steve Charnovitz, 'The Law of Environmental PPMs in the WTO: Debunking the Myth of Illegality' (2002) 27 Yale J. Int'1 L. 59.

$89 \operatorname{COM}(2011) 144$ final (n 7), p. 19, 'Annex I: List of initiatives 1.1., 7. Multimodal transport of goods: e-freight'. The white paper talks about an electronic waybill; however, the system of integrating information on greenhouse emissions could easily be integrated to the existing transport documents, electronic or paper versions.

Columns Design XML Ltd / Job: Chuah-Research_handbook_on_maritime_law_and_regulation / Division: 07Ch7-Eftestol_final /Pg. Position: 15 
All in all, the transport service buyers are not presently required to be informed of the emissions caused from the services they are buying nor are (professional or private) consumers of products and services required to be informed of transport emissions caused by the production model of the (global) supply chain. Disclosing such information is each company's choice of business model instead of a mandatory duty. Policymakers as choice architects will not nudge anyone anywhere towards more sustainable choices on markets. 